http://dx.doi.org/10.5597/lajam00167

\title{
Proposed English common NAMe for the NeOtropical DelPhinid Sotalia Guianensis (P-J. VAN BÉNEdÉn, 1864)
}

\author{
Paulo A. C. Flores ${ }^{1, *}$, Mariel Bazzalo ${ }^{2}$, Susana Caballero ${ }^{3,4}$, Marcos C. de O. Santos ${ }^{5}$, Marcos R. Rossi-Santos 6 , \\ Fernando Trujillo ${ }^{7}$, Jaime Bolaños-Jimenez ${ }^{8}$, Marta J. Cremer ${ }^{9}$, Laura J. May-Collado ${ }^{10}$, Flávio J. L. Silva ${ }^{11}$, \\ Maria Gabriela Montiel-Villalobos ${ }^{12}$, Alexandre F. Azevedo ${ }^{13}$, Ana C. O. Meirelles ${ }^{14}$, Leonardo Flach $^{15}$, \\ Hector Barrios-Garrido ${ }^{16}$, Paulo C. Simões-Lopes ${ }^{17}$, Haydée A. Cunha ${ }^{18}$ and Koen Van Waerebeek ${ }^{19}$
}

Dolphins of the genus Sotalia (Delphinidae) occur along the Atlantic and Caribbean coasts of South and Central America and in the Amazon and Orinoco River basins (Flores and Da Silva, 2009; da Silva et al., 2010 this volume; Gómez-Salazar et al., 2010 this volume). The genus has been divided into two species based on skull morphology (Monteiro Filho et al., 2002) and genetic evidence (Cunha et al., 2005; Caballero et al., 2007; Caballero et al., 2010 this volume). The name Sotalia fluviatilis (Gervais and Deville in Gervais, 1853) has been assigned to animals found in the Amazon River basin (riverine) while Sotalia guianensis (P-J. Van Bénedén, 1864) designates the coastal (marine) species in South and Central America, including the Orinoco River delta and Lake Maracaibo in Venezuela. While the name tucuxi has been widely adopted to refer to the former, for the latter common or vernacular names, whether in Spanish, Portuguese or English, vary depending on local designations across its range. The taxonomic status of dolphins occurring in the lower and middle Orinoco is uncertain and here we refer to them as Sotalia sp.
Along its distribution (Figure 1), S. guianensis is locally known as 'boto', 'golfinho', 'boto comum', 'golfinho-cinza' or 'boto-cinza' off the Brazilian coast; 'bufeo gris', 'bufeo blanco' or 'bufeo negro' in coastal Colombia; 'tonina del lago' in Lake Maracaibo and 'bufeo negro', 'bufete' or 'soplón' in the Orinoco River basin in Venezuela; 'lam' in Nicaragua; Guiana dolphin or Guiana white dolphin in British Guyana and 'profosu' or 'dolfijn' ${ }^{20}$ in Suriname. These names naturally correspond to the different languages spoken in the various range states.

Several common, local names have tentatively been adopted in English (e.g. Geise, 2006), but authors with different linguistic backgrounds usually do not choose the same names. For instance, a review of the published literature on the species from 2002 to 2007 (approximately 60 scientific papers), revealed that for those papers in which at least an English title or abstract was provided, the most frequently used common name was 'marine tucuxi' (e.g. Flores, 1999; Azevedo et al., 2007; Santos and Rosso, 2008), followed by 'estuarine dolphin' (e.g. Rosas and Monteiro Filho, 2002; Souto et

\footnotetext{
${ }^{1}$ Centro Mamíferos Aquáticos, Centro Nacional de Pesquisa \& Conservação de Mamíferos Aquáticos, ICMBio, Rod. Maurício Sirotsky Sobrinho, s/n, km02, Jurerê, Florianópolis, SC, 88053-700, Brasil

${ }^{2}$ Facultad de Ciencias Exactas y Naturales, Universidad de Buenos Aires, Argentina.

${ }^{3}$ Laboratorio de Ecología Molecular de Vertebrados Acuáticos, Departamento de Ciencias Biológicas, Universidad de los Andes, Carrera 1 \# 18 A-10, Bogotá, Colombia

${ }^{4}$ Ecology and Evolution Research Group, School of Biological Sciences, The University of Auckland, New Zealand

${ }^{5}$ Laboratório de Biologia da Conservação de Cetáceos, Programa de Pós-Graduação em Zoologia, Departamento de Zoologia, Instituto de Biociências, Universidade Estadual Paulista 'Júlio de Mesquita Filho', Campus Rio Claro Av. 24-A, 1515, Bela Vista, Rio Claro, SP, Brasil, 13506-900

${ }^{6}$ Instituto Baleia Jubarte, C.P. 92, Praia do Forte, Mata de São João, BA, 48.280-000, Brasil

${ }^{7}$ Fundación Omacha, Calle 86A No. 23-38, Bogotá, Colombia

${ }^{8}$ Sociedad Ecológica Venezolana Vida Marina, A.P. 162, Cagua, Estado Aragua,Venezuela

${ }^{9}$ Universidade da Região de Joinville, Departamento de Ciências Biológicas, Laboratório de Nectologia, C. P. 110, São Francisco do Sul, SC, 89240-000, Brasil

${ }^{10}$ Departmento de Biologia, University of Puerto Rico, Rio Piedras, San Juan, Puerto Rico, 00931

${ }^{11}$ Universidade do Estado do Rio Grande do Norte, Projeto Cetáceos da Costa Branca; Universidade Federal do Rio Grande do Norte Projeto Pequenos Cetáceos; and Centro Golfinho Rotador, Brasil

${ }^{12}$ Laboratorio de Ecologia y Genetica de Poblaciones, Centro de Ecologia, Instituto Venezolano de Investigaciones Cientificas, Caracas 1020-A, Venezuela

${ }^{13}$ Laboratório de Mamíferos Aquáticos, Faculdade de Oceanografia, Universidade do Estado do Rio de Janeiro, R. São Francisco Xavier, 524 sala 4002E, Maracanã, Rio de Janeiro, RJ, 20550-013, Brasil

${ }^{14}$ Associação de Pesquisa e Preservação de Ecossistemas Aquáticos, Praia de Iparana s/n, SESC Iparana, Caucaia, Ceará, 61627-010, Brasil

${ }^{15}$ Projeto Boto Cinza, Rua Santa Terezinha, 531, Vila Muriqui, Mangaratiba, Rio de Janeiro, 23860-000, Brasil

${ }^{16}$ Laboratorio de Ecologia General, Departamento de Biología, Facultad Experimental de Ciencias, Universidad del Zulia, Maracaibo, Venezuela

${ }^{17}$ Laboratório de Mamíferos Aquáticos, Departamento de Ecologia e Zoologia, Universidade Federal de Santa Catarina, C. P. 5102, Florianópolis, SC, 88040-970, Brasil

${ }^{18}$ Laboratório de Biodiversidade Molecular, Departamento de Genética, Instituto de Biologia, Universidade Federal do Rio de Janeiro; and Laboratório de Mamíferos Aquáticos, Universidade do Estado do Rio de Janeiro, Bloco A, Sl. A2-098, Ilha do Fundão, Rio de Janeiro, RJ, 21941-590, Brasil

${ }^{19}$ Centro Peruano de Estudios Cetológicos, Museo de Delfines, Pucusana, Lima-20, Peru

* Corresponding author, e-mail: paulo.flores@icmbio.gov.br, flores.p@terra.com.br

20 'Dolphin' in Dutch
} 
al., 2006; Rossi-Santos et al., 2007). Nomenclatural consistency is clearly lacking, as emphasised by instances in which the same journal has accepted two different names (marine tucuxi and estuarine dolphin) as seen in Azevedo et al. (2007), Rossi-Santos et al. (2007), Rosas and Monteiro Filho (2002), and Santos and Rosso (2008). Recently, yet another name, 'costero,' was proposed in a single article (Caballero et al., 2007). In fact, none of the English common names proposed to date has properly reflected either the species' distribution, habitats or other conspicuous characteristic; all may therefore be considered misleading or inadequate.

During its 2008 Annual Meeting in Santiago, Chile, as proposed by Flores et al. (2008), the Scientific Committee of the International Whaling Commission (IWC) endorsed 'Guiana dolphin' as the common English name for Sotalia guianensis in its IWC List of Recognized Cetacean Species (LRCS), and thus also for its Journal of Cetacean Research and Management (IWC, 2009). The primary rationale accepted by the IWC Scientific Committee related to the geographic area from where this species was first described. In addition, the Committee recognised the consensus achieved by various authors from different countries covering the species' range in proposing the common name.

Here we propose that from now on 'Guiana dolphin' be used as the English common name of $S$. guianensis in the Latin American Journal of Aquatic Mammals (LAJAM), as well as in all related fora such as the Sociedad Latinoamericana de Especialistas en Mamíferos Acuáticos (SOLAMAC, the Latin American Society of Specialists on Aquatic Mammals). Considering the endorsement by the Scientific Committee of the IWC, it would be appropriate and consistent if authors apply the name 'Guiana dolphin' elsewhere as well. It should be emphasised that in proposing this English common name, we are not attempting to propose or define any local names for the species in any of the range states.

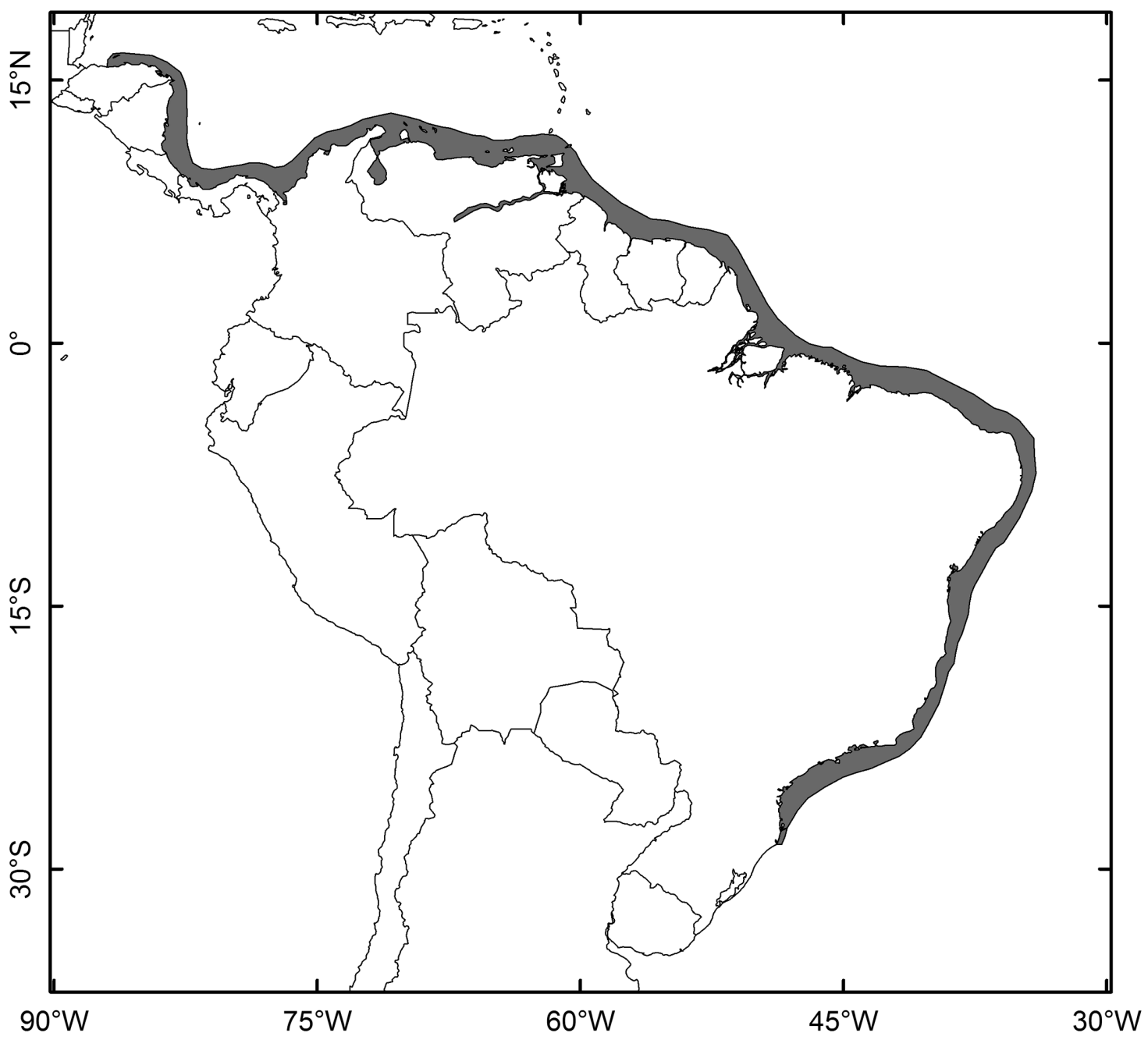

Figure 1. Distribution (area in grey) of the Guiana dolphin Sotalia guianensis in South and Central America (map by Júlia E.C. Oshima). 


\section{Acknowledgments}

We thank Eduardo R. Secchi and Alexandre N. Zerbini for earlier discussions on this paper as well as Greg P. Donovan and Daniel M. Palacios for thoughtful reviews of the manuscript. Júlia E.F. Oshima kindly drew the map in Figure 1.

\section{References}

Azevedo, A.F., Oliveira, A.M., Viana, S.C. and Van Sluys, M. (2007) Habitat use by marine tucuxis (Sotalia guianensis) (Cetacea: Delphinidae) in Guanabara Bay, south-eastern Brazil. Journal of the Marine Biological Association of the United Kingdom 87(2): 201-205. http:/ / dx.doi.org/10.1017/S0025315407054422

Caballero, S., Trujillo, F., Vianna, J.A., Barrios-Garrido, H., Montiel, M.G., Beltran-Pedreros, S., Marmontel, M., Santos, M.C.O., Rossi-SANTOS, M.R., SANTOS, F.R. AND BAKER, C.S. (2007) Taxonomic status of the genus Sotalia: species level ranking for 'tucuxi' (Sotalia fluviatilis) and 'costero' (Sotalia guianensis) dolphins. Marine Mammal Science 23(2): 358-386. http:/ / dx.doi.org/10.1111/j.1748-7692.2007.00110.x

Caballero, S., Trujillo, F., Vianna, J.A., Barrios-Garrido, H., Montiel, M.G., Beltrán-Pedreros, S., Marmontel, M., Santos, M.C.O., Rossi-SANTOS, M.R., SANTOS, F.R AND BAKER, C.S. (2010) Mitochondrial DNA diversity, differentiation and phylogeography of the South American riverine and coastal dolphins Sotalia fluviatilis and Sotalia guianensis. Latin American Journal of Aquatic Mammals 8(1-2): 69-79. http://dx.doi.org/ 10.5597/lajam00155

Cunha, H.A., Da Silva, V.M.F., Laílson-Brito, J.J., Santos, M.C.O., Flores, P.A.C., Martin, A.R., Azevedo, A.F., Fragoso, A.B.L., Zanelatto, R.C. and Solé-Cava, A.M. (2005) Riverine and marine ecotypes of Sotalia fluviatilis are different species. Marine Biology 148(2): 449-457. http://dx.doi.org/10.1007/ s00227-005-0078-2

da Silva, V.M.F., Fettuccia, D., Rodrigues, E.S., Edwards, H., Moreno, I.B., Moura, J.F., Wedekin, L.L., Bazzalo, M., Emin-Lima, N.R., Carmo, N.A.S., Siciliano, S. and Utreras B., V. (2010) Report of the Working Group on Distribution, Habitat Characteristics and Preferences, and Group Size. Latin American Journal of Aquatic Mammals 8(1-2): 31-38. http:/ / dx.doi.org/10.5597/lajam00151

FLORES, P.A.C. (1999) Preliminary results of a photoidentification study of the marine tucuxi Sotalia fluviatilis in southern Brazil. Marine Mammal Science 15(3): 840-847. http://dx.doi.org/ 10.1111/j.1748-7692.1999.tb00846.x

FLores, P.A.C. \& DA SILVA, V.M.F. (2009) Tucuxi and Guiana Dolphin (Sotalia fluviatilis and S. guianensis). Pages 1188-1192 in Perrin, W.F., Würsig, B. and Thewissen, J.G. M. (Eds) Encyclopedia of Marine Mammals. Elsevier, Amsterdam, 2nd ed.

Flores, P.A.C., Bazzalo, M., Caballero, S., Santos, M.C.O., Trujillo, F., Azevedo, A.F., Cremer, M.J., Simões-Lopes, P.C., May-Collado, L.J., Flach, L., Barrios, H., Montiel, M.G., RossiSantos, M.R., Meirelles, A.C.O., Bolaños, J. and Silva, F.J.L. (2008) Proposed English common name of Sotalia guianensis to the IWC List of Recognized Cetacean Species. Paper SC/ 60/SM16 presented to the Scientific Committee of the International Whaling Commission. June 2008, Santiago, Chile. 3 pp. [Paper available at the IWC Secretariat, Cambridge, UK, or at <http://www.iwcoffice.org>].

GEISE, L. (2006) The correct use of the vernacular names for South American dolphins genus Sotalia Gray (Mammalia, Cetacea, Delphinidae). Revista Brasileira de Zoologia 23(4): 12751276. http://dx.doi.org/10.1590/S0101-81752006000400043

Gervais, P. (1853) Remarques sur les mammifères marins qui frequentent les côtes de La France et plus particulièrement sur une nouvelle espèce de Dauphin propre à la Méditerranée. Bulletin de la Societé Centrale d'A griculture et des comices agricoles $d u$ department de l'Herault (Montpellier), 40 année (Avril, Main, Juin): 140-156.

Gómez-Salazar, C., Portocarrero-Aya, M., Trujillo, F., Caballero, S., Bolaños-Jiménez, J., Utreras, V., McGuire, T., Ferrer-Pérez, A., Pool, M., And Aliaga-Rossel, E. (2010) Update on the freshwater distribution of Sotalia in Colombia, Ecuador, Peru, Venezuela and Suriname. Latin American Journal of Aquatic Mammals 8(1-2): 171-178. http://dx.doi.org/10.5597/ lajam00166

International Whaling Commission (2009) Report of the Scientific Committee. Journal of Cetacean Research and Management (Supplement) 11: 1-74.

Monteiro Filho, E.L.A., Monteiro, L.R. And Reis, S.F. (2002) Skull shape and size divergence in dolphins of the genus Sotalia: a tridimensional morphometric analysis. Journal of Mammalogy 83(1): 125-134. http://dx.doi.org/10.1644/15451542\%282002\%29083\%3C0125:SSASDI\%3E2.0.CO;2

Rosas, F.C.W. And Monteiro Filho, E.L.A. (2002). Reproduction of the estuarine dolphin (Sotalia guianensis) on the coast of Parana, southern Brazil. Journal of Mammalogy 83(2): 507-515. http:/ / www.bioone.org/doi/abs/10.1644/1545$1542 \% 282002 \% 29083 \% 3$ C0507\%3AROTEDS\%3E2.0.CO\%3B2

Rossi-Santos, M.R., WedeKIN, L.L. AND Monteiro Filho, E.L.A. (2007) Residence and site fidelity of Sotalia guianensis in the Caravelas River Estuary, eastern Brazil. Journal of the Marine Biological Association of the United Kingdom 87(2): 207-212. http:/ / dx.doi.org/10.1017/S0025315407055683

SAnTos, M.C.O. AND Rosso, S. (2008). Social organization of marine tucuxi dolphins, Sotalia guianensis, in the Cananéia estuary of Southeastern Brazil. Journal of Mammalogy 89(2): 347355. http://dx.doi.org/10.1644/07-MAMM-A-090R2.1

Souto, A., Araújo, J.P., Geise, L. and Araújo, M.E. (2006) The surface behavior of the estuarine dolphin in Baía dos Golfinhos, RN, Brazil: a field and comparative study. Revista Brasileira de Zoociências 8(2): 183-192.

Van Beneden, P-J. (1864) Sur un Dauphin nouveau (Delphinus guianensis) et un Ziphioide rare. Mémoires de l'Académie Royale de Sciences de Belgique 16(1): 1-21.

Received on 23 July 2008. Accepted on 13 June 2010. Managed by Monica Borobia. 
